\title{
Halal Awareness Effect on Malaysian Muslims' Intention to Visit Homestays in Sabah, Malaysia: The Moderating Role of Gender
}

\section{Azrin Bin Jalasi, Sylvia Nabila Azwa Ambad}

To Link this Article: http://dx.doi.org/10.6007/IJARBSS/v11-i9/10888

DOI:10.6007/IJARBSS/v11-i9/10888

Received: 18 July 2021, Revised: 21 August 2021, Accepted: 04 September 2021

Published Online: 20 September 2021

In-Text Citation: (Jalasi \& Ambad, 2021)

To Cite this Article: Jalasi, A. Bin, \& Ambad, S. N. A. (2021). Halal Awareness Effect on Malaysian Muslims' Intention to Visit Homestays in Sabah, Malaysia: The Moderating Role of Gender. International Journal of Academic Research in Business and Social Sciences, 11(9), 1538-1554.

\section{Copyright: (c) 2021 The Author(s)}

Published by Human Resource Management Academic Research Society (www.hrmars.com)

This article is published under the Creative Commons Attribution (CC BY 4.0) license. Anyone may reproduce, distribute, translate and create derivative works of this article (for both commercial and non-commercial purposes), subject to full attribution to the original publication and authors. The full terms of this license may be seen at: http://creativecommons.org/licences/by/4.0/legalcode

Vol. 11, No. 9, 2021, Pg. 1538 - 1554

Full Terms \& Conditions of access and use can be found at http://hrmars.com/index.php/pages/detail/publication-ethics 


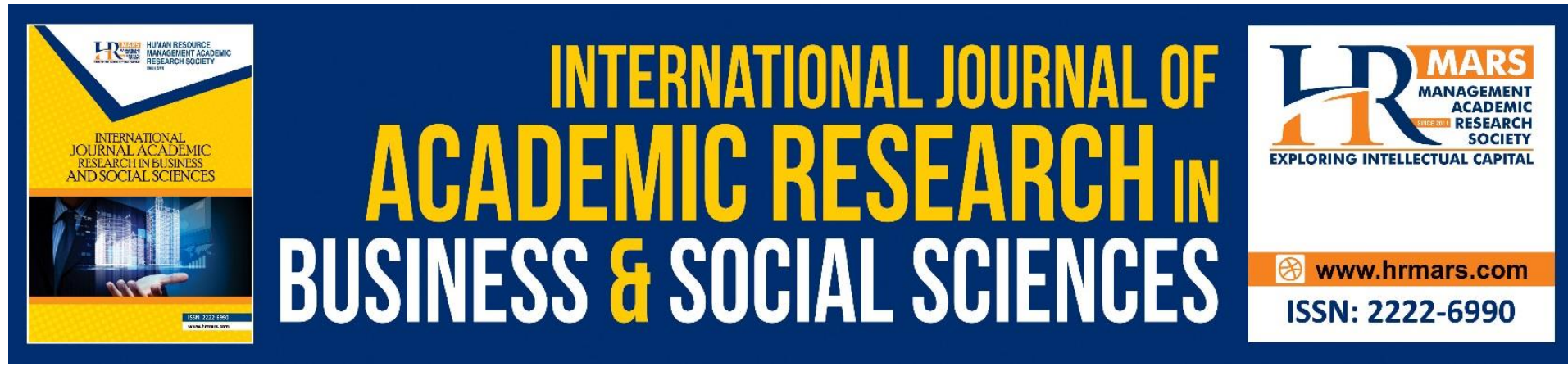

\title{
Halal Awareness Effect on Malaysian Muslims' Intention to Visit Homestays in Sabah, Malaysia: The Moderating Role of Gender
}

\author{
Azrin Bin Jalasi ${ }^{1}$, Sylvia Nabila Azwa Ambad ${ }^{2}$ \\ ${ }^{1}$ Arshad Ayub Graduate Business School, Universiti Teknologi MARA, Sabah \\ Branch, Kota Kinabalu Campus, Malaysia, ${ }^{2}$ Faculty of Business and Management, \\ Universiti Teknologi Mara, Sabah Branch, Kota Kinabalu Campus, Malaysia \\ Email: azrin_jalasi@hotmail.com
}

\begin{abstract}
Even though the importance of halal awareness in determining Muslims' purchase intentions is recognized in the marketing literature, empirical research on this issue, particularly in the tourism context, is still limited. Hence, to fill this knowledge gap, this study examines the effect of halal awareness on Malaysian Muslims' intention to visit homestays in Sabah, Malaysia. Besides, gender was tested as a moderator in the hypothesized relationship. A quantitative cross-sectional approach was applied to gather data from a sample of 72 males and 72 females of local Malaysian Muslims. A convenience sampling method was employed to collect data for the study. Data collected were analyzed using SmartPLS 3.3.2.9 software. The study's findings indicate that halal awareness significantly influences Malaysian Muslims' intention to visit homestays in Sabah, Malaysia. Additionally, the link between halal awareness and the Muslims' intention to visit the homestays in Sabah are moderated by the factor of gender. The results indicate that the female respondents are having a higher halal awareness than the male respondents.
\end{abstract}

Keywords: Halal Awareness, Intention, Muslims, Homestays, Gender

\section{Introduction}

Undoubtedly, many countries got benefits for supporting Islamic tourism. It further helps them stay competitive and increase their market share in the global tourism market (Jeaheng, Al-Ansi \& Han, 2019). Hence, the Muslim tourism market is acknowledged as another essential segment for international tourism sectors. Many countries worldwide are now realizing the importance of Islamic tourism and taking actions to provide a range of benefits and advantages to Muslim visitors (Oktadiana, Pearce \& Chon, 2016). In Malaysia, one of the tourism products with a unique priority from the government is the homestay program (Ibrahim, 2004). This program is creating an opportunity for the local communities, especially in a rural area, to contribute to the local economic development. Still, it also plays a significant role in reducing the rural area's poverty rate (Kasim et al., 2016).

The demand for homestays in Malaysia is growing faster and has become a popular option for local and foreign tourists. The history of the homestay program in Malaysia started 
in Pahang. In the 70s, a local lady named Mak Long initiated to provide breakfast, dinner, and accommodation in her house to a group of guests at the Kampung Cherating Lama, Pahang (Ibrahim, 2004). Later in 1988, the homestay program was officially launched by the Malaysian government. Remarkably, after decades the number of local people involved in the program started to burgeon impressively. At present, there are 4,272 participants or houses registered under the "Homestay Program" in Malaysia. Many of these homestay accommodations are build up in rural areas all over the country (MOTAC, 2021).

Generally, the homestay program in Malaysia is synonym with community-based tourism activities (CBT). The basic concept of the homestay program in Malaysia is that the tourists will stay with the selected host's family and have a chance to experience the family's daily life in all manners (Ibrahim, 2004). Malaysia's homestay program is not merely an accommodation but also a tourism experience of local people's lifestyle, culture, and economic activities. Before the COVID-19 pandemic, the demand for homestays in Malaysia has shown a tremendous increase for the past few years. The number of tourist arrivals to homestays in Malaysia, domestic and international tourists, increased from 372,475 in 2018 to 458,899 in 2019 (MOTAC, 2019). This positive increase proves that the homestay program is impacting the Malaysian tourism sector significantly. Thus, the homestay program has been recognized as an essential catalyst for economic development in the country.

In Malaysia, the homestay sector in Sabah has recently shown the most progressive growth in the business. Sabah's homestay program was listed as the highest-earning in the industry in 2019, with over MYR6 million in revenue (Daily Express, 2020). In the same year, Sabah was also recognized as the leading tourists' destination for homestays in Malaysia and honoured as 'Malaysia's Favourite Destination' at the 47th edition of the Malaysian Association of Tour and Travel Agents (MATTA) Fair in the year 2019. However, there is a debate over whether or not homestays in Malaysia (particularly Sabah) are Sharia-compliant in this industry. Even though the Malaysian homestays attract more tourists, many did not focus on Islamic matter values (Othman, 2019; Othman et al., 2015).

As a consequence, Muslim tourists experience discomfort as a result of this. Hasan et al. (2016) claim that tourism accommodations lacking particular Shariah regulations have caused Muslim guests to experience disruptions and difficulties (Hasan et al., 2016). At present, Malaysia has developed halal hotels but has yet to establish halal homestay. The halal certification in the homestays sector in Malaysia is still not thorough. Hence, halal certification in the homestays sector in Malaysia is suggested. The inability of destinations hosts to deliver accommodation facilities congruent with Islamic principles creates a dilemma for Muslim travellers (Zamani-Farahani \& Henderson, 2010). It also discourages most of them to visit particular destinations (Battour \& Battour, 2010). Without a doubt, the halal concept is an absolute key to consumption for Muslims, even during travelling.

Over the decades, the halal concept has been the main concern for Muslim consumers. The fulfilment of religious needs is vital for Muslims since their needs and wants are determined by their firm's belief in Islam (Henderson, 2003). Muslims must follow halal and haram's guidelines in all facets of their everyday lives, even during travelling. Islam requires them to adhere to what is lawful and unlawful for human consumption, as stated in the holy book of the Quran (Al-Maidah: 3; Al-Baqarah: 173). The Quran says, "all Muslims should consume halal and good foods" (Al-Baqarah: 168; Al-Mu'minun: 51). This guideline is not limited to foods and drinks only, but it also covers the services. Therefore, studying the role of halal awareness in determining the Muslims' intention to purchase tourism services like homestay is crucial since it has emerged as a critical aspect of Islamic tourism. Moreover, 
although the vital role of halal awareness in determining purchase intention has been recognized in the marketing literature, empirical examination of this issue is still limited (Aziz \& Chok, 2013).

According to Shaari and Ariffin (2009), awareness of halal is the level of knowledge Muslim consumers find and consume halal products according to Sharia laws. Yunus et al., (2014) state that halal influences consumer purchase intention. So, in this case, awareness can be described as a level of attentiveness or realization among Muslim towards consuming or using what is permitted for Muslims to consume and use (Ambali \& Bakar, 2013). Every Muslim has a different level of awareness based on their background, religion, culture, education and social interaction (Rasli, 2013). The level of awareness may lead to Muslim tourists' satisfaction as well as encourage multiple return visits. Muslims ought to follow Islamic teachings that directly and indirectly impact their decisions concerning leisure and travel plans (Zamani-Farahani and Henderson, 2010). Meanwhile, Riaz and Chaundry (2004) have asserted several factors that influence consumption, including religion, race, knowledge, perception, etc. Religious belief leads a Muslim to do what is commanded and forsaken and forbidden by God. Machali et al., (2013) say that in Islam, the concept of halal is the primary key in consumption. Bonne and Verbeke (2006) also explain that Muslim consumers consume Halal foods to follow and express their religious teachings.

Thus, as mentioned earlier, this issue motivates this study to confirm to what extent halal awareness affects the Malaysian Muslim tourists' intention to visit homestays in Sabah. In addition, this study also aims to examine the gender role in strengthen or weaken the relationship between halal awareness (independent variable) and intention to visit homestays (dependent variable). Hopefully, the findings of this study can help homestay operators and marketers to get a better understanding of the halal awareness role in forming the local Malaysian Muslims' intention to visit homestays in Sabah. This understanding also can help the homestay operators and marketers to develop effective marketing strategies to attract more Muslims to visit homestays in Sabah. More importantly, this study's findings can help them improve their homestay accommodation services in line with Muslim tourists' expectations in the future.

\section{Methodology}

\section{Respondent Profile}

Respondents of this study are the local population of Muslims in Malaysia. Respondents were selected based on the eligibility criteria established for the selection of the samples. A total of 200 questionnaires were distributed to selected local Malaysian Muslims in the country. After removing questionnaires with incomplete and irrelevant answers, the remaining samples consisted of 144 respondents ( 72 males and 72 females). Most of the respondents were aged between 18 to 20 years old (58 respondents), which represented 40.3 percent of the total samples. It is followed by respondents aged between 21 to 30 years old (29 respondents) and 41 to 50 years old ( 29 respondents). Both are respectively represented by 20.1 percent of the total samples. Out of the 144 respondents, 17.4 percent of them were from the age group between 31 to 40 years old ( 25 respondents), and 2.1 percent was those above 51 years old ( 3 respondents). With regards to the respondents' occupation, data collected showed that the majority of the respondents were students, representing 50.7 percent of the total samples (73 respondents). This is followed by working respondents that made up of 38.9 percent (56 respondents), while 6.9 percent (10 respondents) were self- 
employed. About 2.1 percent of the respondents are unemployed ( 3 respondents) and the rest are under other occupations (1.4 percent or 2 respondents).

\section{Sampling Technique and Data Collection Method}

This study is quantitative research, and data were collected through a self-administered questionnaire that examines the Halal awareness influences on the local Malaysian Muslims' intention to visit homestays in Malaysia, with gender as the moderator of the relationship. Non-probability convenience sampling was used as a sampling technique in this study. Convenience sampling refers to the collection of information from accessibly available samples. Convenience sampling is perhaps the best way to quickly and efficiently obtain information (Sekaran \& Bougie, 2016). The study utilized a self-administrated questionnaire and conducted surveys in several selected mosques. The online survey was also conducted via Google document and sent through social networks and emails. Data collection was conducted in the early month of August 2020. The statistical SmartPLS 3.2.9 software was applied to analyze the data obtained from the respondents.

\section{Measurement}

All items proposed to measure the factors in this empirical investigation were adapted from previously validated instruments and revised so that the focus was on the local Muslims' intention to visit homestays in Malaysia. The construct of intention was measured with scales adapted from Lam \& Hsu (2006), while the Halal awareness of Muslims was measured using the scales from Aziz and Chok, (2013) and Awan et al., (2015). A 7-point Likert scale was used to reflect the respondents' answers.

\section{Literature Review \\ Muslims' Intention}

Actual behaviour is a result of a strong individual's intention to perform a specific action. It is a subjective probability to adopt or not adopt a particular form of behaviour (Correia, Santos and Barrwo, 2007). According to Yunus et al (2014), intention is an essential key antecedent of actual behaviour (Yunus et al., 2014), and it shapes consumers purchase behaviour (Nguyen et al., 2010). Earlier, Fishbein and Ajzen (1975) defined the intention to measure the strength of one's intention to perform a specific behaviour. Later, in his further studies, Ajzen (1985) defined intention as the state where a person is willing to perform some behaviour. Other studies like Swan (1981) meanwhile associated intention with an individual's expected or planned future behaviour. Similarly, Conner and Armitage (1998) defined intention as an individual's motivation in the sense of their conscious plan or decision to exert effort to enact the behaviour. Other studies like Courneya (1994) extended the definition of intention by associating it with the frequency of achievement in physical activity participation.

In marketing, the intention is related to the brand selection tendency (Patwary \& Rashid, 2016). It is an indication of the possibility that consumers will be planning or willing to buy certain products or services in the future (Wu, Yeh and Hsiao, 2011). In the context of Muslim consumers, faith is part of the intention and purchase decision. For Muslims, the process of searching for products or services must be faith-based needs. To be specific, in tourism, Muslims prefer to choose a destination where Islamic attributes are highly available. It may allow for tourism activities that fall within their religious norms and practices comprising facilities for prayer and worship, no liquor, Halal foods, and Islamic dress codes (Battour et 
al., 2013; Olya \& Al-Ansi, 2018). Thus, in this study, intention refers to Muslims readiness to visit homestays.

\section{Halal Awareness}

Awareness generally refers to an individual's ability to understand a particular issue (Awan et al., 2015). According to Ambali and Bakar (2014), the issue could be related to what a person eats, drink, and use. Their studies have asserted that awareness is the result of an individual's perception and intellectual response. In other studies, Aziz and Chok (2013) have defined awareness as an ability to see, feel, and be sensible of events or objects. According to Aziz and Chok (2013), awareness focuses more on the human's understanding and information about specific things. However, halal awareness is imperative for a Muslim when it comes to the Muslims' consumption issue. According to Yunus et al (2014), halal awareness is vital for Muslims to avoid anything doubtful and uncertain.

Hence, in the context of Islam, halal awareness can be defined as the act of concern about something permissible in Islam (Patwary et al., 2018; Yunus et al., 2014). In other Islamic studies, Azam (2016) has defined halal awareness as consumers' knowledge, experience, and special interest regarding purchasing a particular product or service based on Islamic principles. In the same agreement, Suki and Salleh (2016) further asserted that halal is essential to understand the permissibility for a product or service based on the teachings of the Holy Quran. According to Deuraseh (2009), halal and haram is also essential to symbolize what is permissible and not permissible in Islam. Therefore, in this study, halal awareness refers to the Muslims' special interest, experience, or knowledge regarding the purchase of homestay services based on Islamic principles.

\section{The Halal Awareness Effect towards Muslims' Intention}

Over the decades, the halal concept has been the main concern for Muslim consumers when deciding to purchase particular products or services. The concept of halal is crucial for Muslims because Islamic values profoundly influence their social etiquette and consumption patterns (Khraim, 2010). According to Lada et al (2009), 70 per cent of the Muslim population at the global level follow the halal standard. This statistic shows that halal is a priority of most Muslim consumers globally (Lada et al., 2009). In Islamic marketing literature, halal awareness was proven as one of the Muslim consumers' purchase intention determinants (Patwary, 2018; Aziz \& Chok, 2013). Without full knowledge about particular products or services, there is a high possibility that the Muslims will not buy the products or services. Only when they possess more knowledge about the "halalness" of particular products or services they will decide to buy it (Hamdan et al., 2013).

According to Islamic guidelines, Muslim consumers who have an intrinsic halal awareness tend to implement religious values in all aspects of their life. They will make sure the "halalness" of what they are consuming. Meanwhile, Muslim consumers with extrinsic halal awareness will follow the commitment from their beliefs through the information obtained, such as looking at halal information from the products consumed without really finding out more. As a result of greater awareness and knowledge regarding halal and haram among Muslim consumers, marketers are no longer able to get away from the "halalness" issue by adding a halal logo to the package (Said et al., 2014). For Muslim, awareness of halal has a significant influence on their decisions to buy products or services. Halal awareness has emerged as a crucial issue in the decision-making process of Muslim consumers (Teng \& Jusoh, 2013). The findings of studies like Azam (2016); Said et al., (2014) indicate a significant 
and positive relationship between Muslims' halal awareness and their behavioural intention. Their past investigation of Muslim halal awareness suggests that the Muslim consumers' Halal awareness can influence their intentions to purchase particular products or services.

Similary, Haque et al (2019); Ghadikolaei (2016); Yunus et al (2014) have also found that there is a significant relationship between Halal awareness and purchase intention among Muslim consumers. These findings implied that Muslim consumers are aware of the importance of buying Islamic products and services. Few scholars suggested the Halal awareness's influence on clarifying the consumers' intention to purchase halal products was emphasized (Zakaria et al, 2017; Aziz \& Chok, 2013). The studies of Zakaria et al (2017) have revealed that halal awareness positively affects the consumers' purchase intention. This finding supports Hamdan et al (2013) revelation that the most influential factor in determining Muslim consumers' decision to buy halal food is their level of awareness about particular products. In agreement with this finding, Aziz and Chok (2013) also reported a positive influence on consumer attitude toward buying food products.

Studying the determinants of Muslim's purchase intention, Ghadikolaei (2016) also uncovered that halal awareness shares a significant relationship with Muslim consumers' purchase intention. In other research, Yunus et al (2014) meanwhile reported that the halal awareness of a Muslim consumer has a significant effect on his or her purchase intention. The higher the consumer's Halal awareness level, the higher the consumer's purchase intention towards Sharia-compliant products and services. Nevertheless, the relationship between Halal awareness and intention to purchase is not always positively significant. For example, Awan et al., (2015), in their studies, found that there is no significant impact of halal awareness on the consumers' purchase intention in halal food products. This result might be due to the differences in types of sampling. Therefore, in this study, the following hypothesis is developed.

Hypothesis 1: There is a significant positive influence of halal awareness on the Muslims' intention to visit homestays in Sabah.

\section{The Moderating Effects of Gender}

Gender is one of the most crucial human's characteristics (Hwang \& Kim, 2019). Due to this fact, many researchers have focused their studies on gender differences in various contexts such as phycology, education, tourism, marketing and consumer behaviour. Previously, gender has been discussed as a significant factor for perception, attitude and choice of food (Bellows et al., 2010). In the context of consumer behaviour, researchers have consistently found that although a product has the same importance for both genders, a variable effect on consumer behaviour may differ depending on gender. According to Oh et al (2002), gender difference could significantly affect the consumers' behaviour and decision-making process. In the same agreement, Meyers-Levy and Maheswaran (1991) asserted that in information processing, women are more extensively engaged in the processing of information than men. In their studies, they also found that men are not proactively involved in such information processing.

In the context of the decision-making process, the findings of studies like Chua et al., (2019) indicate the different results of studies between women and men. According to Chua et al., (2019), women are more concentrated on the consumption process. Their decisionmaking process is more likely to be influenced by their emotion regarding the decisionmaking process. On the other hand, men are less concentrated on the consumption process, 
and their decision-making process is less affected by emotion. The previous studies also revealed that gender difference influences an individual's thought, action, perception, and preferences in line with this finding. Similarly, Rapport et al (1993) have postulated that gender difference can influence an individuals' perception and preferences. The studies of Chen et al (2014) further support the findings with similar assertion. According to Chen et al., (2014), women were found to place more value on healthiness, safety, pleasure, and convenience than men regarding perception and preferences. Likewise, in term of thoughts and action, women are far less likely than men to turn their ideas into action (Haus et al., 2013).

Previously, several empirical studies have been conducted to examine the moderating role of gender (Tiraieyari et al., 2019; Leeuw et al., 2014; Emmanuel., 2012; Tang et al., 2011; Ryu \& Han, 2010; Blanchard et al., 2009). For example, Leeuw et al (2014) discovered that attitude on intention is more robust among male college students in buying fair trade products while perceived behavioural control was more robust among female college students. In another set of studies, Ryu and Han (2010) found a consistent finding on the moderating role of gender on the relationship between attitudes to try out local cuisine while travelling. While the link between subjective norm and the intention of eating sweet snacks does not vary across male and female consumers, female consumers are more likely to perceive a higher pressure among female consumers not to consume sweet snacks (Grogan et al., 1997). A few studies found the stronger effect of subjective norm on the intention among females in volunteering in urban agriculture (Tiraieyari et al., 2019) and in purchasing mass customized products (Tang et al., 2011).

However, not all studies in the past have found similar results. Some studies such as Blanchard et al (2009); Emanuel et al (2012) have found that gender did not exert any significant impact on any path among TPB variables (attitude, subjective norm and perceived behavioural control) in consuming vegetables and fruits. The results indicate that the moderating role of gender has been inconclusive for the past few years. Hence, detecting moderating effects of gender in the current study is vital because tailored intervention or marketing messages to a specific group of target consumers maximize the effectiveness of marketing efforts such as building a solid brand (Blanchard et al., 2009; De Leeuw et al., 2014). It is deemed worthwhile to investigate the moderating effects of gender to understand better Muslims' halal awareness and their intention to visit homestay. Moreover, the gender moderating influences in Halal awareness and Muslims' intention are still limited. Therefore, the hypothesis below is developed.

Hypothesis 2: Gender moderates the relationship between Halal awareness and Muslims' intention to visit homestays in Sabah.

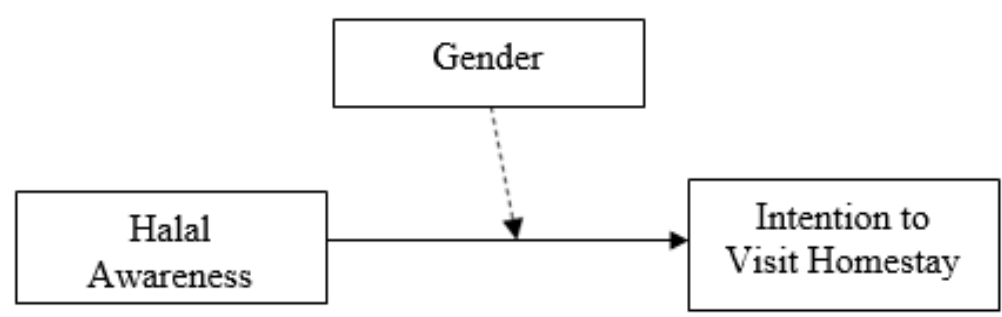

Figure 1: Conceptual framework 
The framework of the study as shown in Figure 1 indicates the Muslims' Halal awareness as the independent variable and the Muslims' intention to visit homestays in Malaysia is the dependent variable. Meanwhile, gender is used as a moderator in the hypothesized link.

\section{Findings}

\section{Reliability and Validity of Measurements}

In PLS-SEM, the first stage is to perform the measurement assessment to ensure that all variables' validity and reliability are satisfactory prior to hypotheses testing. In this stage, the following assessments were performed:

i. Internal consistency - Cronbach's Alpha, Composite reliability, pA-Dijkstra Henseler's rho'

ii. Convergent validity - Factors loading and Average Variance Extracted (AVE)

iii. Discriminant validity - Fornell and Larcker Criterion, Cross Loadings and Heterotrait-Monotrait Ratio of Correlations (HTMT)

As shown in Table 1, no items under intention (INT) and Halal Awareness (HA) were removed due to low loading (less than 0.70), as suggested by Chin (1998). In general, all internal consistency and convergent validity were satisfactory. Each construct achieved the composite reliability coefficients above the recommended cut-off of 0.7 (see Table 1 ). Therefore, items within each variable show high internal consistency and high reconstruction of the findings, as suggested by Fornell \& Larcker (1981). 
Table 1: Result of the reflective measurement model

\begin{tabular}{|c|c|c|c|}
\hline Variables and Items & $\begin{array}{l}\text { Factor } \\
\text { Loading }\end{array}$ & $\begin{array}{l}\text { Composite } \\
\text { Reliability }\end{array}$ & $\begin{array}{l}\text { Average } \\
\text { Variance } \\
\text { Extracted }\end{array}$ \\
\hline 1) Intention (INT) & & 0.957 & 0.849 \\
\hline $\begin{array}{l}\text { I am likely to choose homestay as a vacation stay in the } \\
\text { future. }\end{array}$ & 0.913 & & \\
\hline $\begin{array}{l}\text { I am likely to encourage others to stay at a homestay } \\
\text { when traveling in the future. }\end{array}$ & 0.928 & & \\
\hline $\begin{array}{l}\text { I intend to stay at a homestay when traveling within the } \\
\text { next three years. }\end{array}$ & 0.950 & & \\
\hline $\begin{array}{l}\text { I am interested to stay at a homestay when traveling } \\
\text { within the next three years. }\end{array}$ & 0.894 & & \\
\hline 2) Halal Awareness (HA) & & 0.968 & 0.834 \\
\hline $\begin{array}{l}\text { I will only visit a homestay if it is following the rules of } \\
\text { Islam. }\end{array}$ & 0.947 & & \\
\hline $\begin{array}{l}\text { I will only visit a homestay if I know it is complying the } \\
\text { rules of Islam. }\end{array}$ & 0.950 & & \\
\hline $\begin{array}{l}\text { I will make sure the homestay is following the rules of } \\
\text { Islam before making a book. }\end{array}$ & 0.935 & & \\
\hline $\begin{array}{l}\text { The government is responsible to ensure the homestays } \\
\text { are Muslim friendly for Muslim guests. }\end{array}$ & 0.867 & & \\
\hline $\begin{array}{l}\text { The homestays operators are responsible to ensure the } \\
\text { homestays are Muslim friendly for Muslim guests. }\end{array}$ & 0.898 & & \\
\hline $\begin{array}{l}\text { I will make sure to have enough knowledge to make } \\
\text { decision. }\end{array}$ & 0.878 & & \\
\hline
\end{tabular}

\section{Discriminant Validity}

The discriminant validity of Fornell and Larcker Criterion, Cross Loadings, and HeterotraitMonotrait Ratio of Correlations (HTMT) was performed, which demonstrated adequate Fornell and Larcker's criterion. Besides, the cross-loading indicates that discriminant validity is achieved, as the constructs are distinctly different from each other. The result in Table 2 indicates that the HTMT values fulfil the recommendations by Henseler et al. (2015), which does not exceed 0.90 . Hence, demonstrating evidence of discriminant validity that indicates the degree to which one construct differs from the other.

Table 2: Heterotrait-Monotrait Ratio of Correlations (HTMT) Results

\begin{tabular}{lcc}
\hline & $\begin{array}{c}\text { Halal Awareness } \\
\text { (HA) }\end{array}$ & $\begin{array}{c}\text { Intention to Visit } \\
\text { (INT) }\end{array}$ \\
\hline Halal Awareness (HA) & & \\
Intention to Visit (ITN) & 0.322 \\
\hline
\end{tabular}

HTMT $<0.90$ 
Table 3: Fornell and Larcker Criterion Results

\begin{tabular}{lcc}
\hline & $\begin{array}{c}\text { Halal Awareness } \\
\text { (HA) }\end{array}$ & $\begin{array}{c}\text { Intention to Visit } \\
\text { (INT) }\end{array}$ \\
\hline Halal Awareness (HA) & 0.913 & \\
Intention to Visit (ITN) & 0.322 & 0.921 \\
\hline
\end{tabular}

\section{Results of Hypotheses Testing}

The second stage of Smart-PLS is the assessment of the structural model or hypotheses testing. The hypotheses in this study were tested using the bootstrap re-sample technique with an iteration of 5000 sub-sample. As shown in Table 4, Halal awareness and the Muslims' intention to visit homestays ( $\mathrm{H} 1: \beta=0.329, \mathrm{p}=0.000)$ are having significant relationships. Next, Table 5 exhibits the moderating effect of gender. As anticipated, the result of the hypothesis is significant. Therefore, $\mathrm{H} 1$ and $\mathrm{H} 2$ are supported. Further, the effect size of the independent variables was assessed to determine their effect on Muslims' intention to visit homestays. According to Cohen (1988), effect size ( $f 2$ ) values above $0.02,0.15$, and 0.35 represent small, medium, and large effect. Thus, as shown in Table 4, the $f 2$ value of Halal awareness ( $f 2=0.116$ ) suggested that Halal awareness has small effect size on the local Muslims' intention to visit homestays in Malaysia. Meanwhile, the R2 value for intention to visit is 0.098 , which indicates that 9.8 percent of the variance in Muslims' intention to visit homestays in Malaysia can be explained by Halal awareness. As suggested by Cohen (1988), the $\mathrm{R} 2$ value that exceeded 0.26 indicates its substantial level of predictive accuracy.

Table 4: Hypotheses and Result for Direct Effect

\begin{tabular}{|c|c|c|c|c|c|c|c|}
\hline Relationship & $\begin{array}{c}\text { Path } \\
\text { Coefficient }\end{array}$ & $\begin{array}{l}\text { Standard } \\
\text { Deviation }\end{array}$ & $\begin{array}{c}\mathbf{T} \\
\text { Value }\end{array}$ & $\begin{array}{l}\mathrm{LLCl} \\
(5 \%)\end{array}$ & $\begin{array}{l}\text { UCLI } \\
(95 \%)\end{array}$ & P Values & Supported \\
\hline \multirow[t]{3}{*}{$H A>I N T$} & 0.329 & 0.09 & 3.571 & 0.177 & 0.462 & 0 & Yes \\
\hline & \multicolumn{2}{|c|}{ Relationship } & f2 & \multicolumn{2}{|c|}{$\mathbf{R 2}$} & & \\
\hline & \multicolumn{2}{|r|}{$H A>I N T$} & 0.116 & \multicolumn{2}{|c|}{0.098} & & \\
\hline Relationship & $\begin{array}{c}\text { Path } \\
\text { Coefficient }\end{array}$ & $\begin{array}{l}\text { Standard } \\
\text { Deviation }\end{array}$ & $\begin{array}{c}\text { T } \\
\text { Value }\end{array}$ & $\begin{array}{l}\mathrm{LLCl} \\
(5 \%)\end{array}$ & $\begin{array}{c}\text { UCLI } \\
(95 \%)\end{array}$ & P Values & Supported \\
\hline $\begin{array}{c}\mathrm{HA}>\mathrm{GENDER}- \\
\quad>\mathrm{INT}\end{array}$ & -0.241 & 0.088 & 2.791 & -0.406 & -0.068 & 0.005 & Yes \\
\hline
\end{tabular}

\section{Conclusion and Recommendations}

This research aims to examine the influence of halal awareness on the Muslims' intention to visit homestays in Malaysia. Specifically, this study has proposed that halal awareness effect the Muslims' intention to visit homestays in Malaysia. In addition, this study also hypothesized that gender moderates the relationship between the two variables. Technically, this study examines the relationships between halal awareness and Muslims' intention to visit homestay using SmartPLS 3.3.2.9. Overall, the study achieved its objectives through a 
questionnaire survey distributed to 144 Malaysian Muslims, 72 women and 72 men. The results inferred that Muslims' halal awareness influence their intentions to visit homestays in Malaysia. The Muslims' intention to visit homestay is very much affected by their awareness and knowledge regarding halal. Without full knowledge about the 'halalness' of particular products and services, the Muslims will have lower intention to buy the products or services.

Besides, this study also concluded that gender difference could moderate the relationship between halal awareness and Muslims' intention to visit homestays. The results of the data analysis have the following significant findings. First, the results of the data analysis showed that halal awareness plays a critical role in influencing Muslims' intention to visit homestays in Malaysia $(0.329, p<0.05)$. The results interpret that if Muslim visitors have a higher level of halal awareness, they are more likely to have higher intentions to visit Muslim-friendly homestays. This finding was consistent with the results of studies from Haque et al (2019); Patwary (2018); Zakaria et al (2017); Ghadikolaei (2016); Yunus et al (2015); Aziz and Chok (2013); Hamdan et al (2013). From this perspective, this study has an important practical implication because of the vital role of halal awareness in forming the Muslims' intention to purchase services like homestays.

For Muslims, adherence to religious principles is of utmost importance because their belief in Islam shapes their decisions. Henceforth, in the context of accommodation like a homestay, Muslims will seek accommodation services that comply with the Shariah principles. Second, the data analysis results indicated that gender plays a moderating role in the relationship between halal awareness and Muslims' intention to visit homestays. This finding is following the results of studies from Tiraieyari et al., (2019), Leeuw et al., (2014), Ryu and Han (2010); Grogan et al (1997). The previous studies suggested that gender differences are significant in strengthening or weakening the relationship between specific predictor and consumers' behavioural intention. Hence, this study assumes that gender differences can strengthen or weaken the relationship between Muslims' halal awareness and their intention to visit homestays in Malaysia.

Another notable finding of this study is that Muslim women have higher halal awareness than Muslim men regarding the intention to visit homestays. This finding was supporting the previous researches of Chua et al (2019); Chen et al (2014); Haus et al (2013); Rapport et al (1993) and Meyers-Levy and Maheswaran (1991). It suggests that Muslim women are more likely to show higher halal awareness than Muslim men in the context of choosing and visiting homestays. Overall, the study results contribute to the extant related literature and support the results of previous studies. In conclusion, all hypotheses developed for this study are supported. Remarkably, this study has several significant contributions. Theoretically, the findings of this study extended the original concept of the Theory of Planned Behavior (TPB) (Ajzen, 1991).

The TPB model is one of the most applicable paradigms in predicting and understanding the intentions and behaviours of humans (Ting et al., 2016). This model has demonstrated the best way to predict an individual's consumption intention (Ajzen, 1991). However, the three existing predicting variables of TPB (attitude, subject norms and perceived behavioural control) do not always predict consumers' behavioural intention. According to Ajzen (1991), other factors influence consumers' behavioural intentions. According to Ajzen (1991), the addition of a new component in the existing variables of TPB model will strengthen the prediction power of the model. Therefore, the inclusion of halal awareness predictor of consumers' behavioural intention is another notable contribution of this study. Specifically, this study has proven halal awareness as another critical predictor of Muslims' behavioural 
intention. In addition, the inclusion of gender as a moderating variable to the hypothesized link also contribute to the existing marketing literature, especially in Islamic marketing literature.

Further, understanding how halal awareness affects Muslims' intention to visit homestays in Malaysia will lead to establishing Muslim-friendly homestays in Malaysia. In this regard, plans to market homestays for Muslim tourists should be guided by Shariah rules. The success of marketing destinations for Muslim tourists depends on Islamic teachings in tourism activities (Battour et al., 2011). All in all, homestays operators and policymakers need to be more concerned about the availability of Shariah-compliant homestays and establish more Muslim-friendly homestays in the future. However, at present halal certification in the Malaysian homestay sector is still seeming not thorough. Therefore, this empirical paper will be helpful for researchers, homestay operators, and related government agencies. As with other studies, this study also faces some limitations, which lead to suggestions for future research paths. The first limitation is in term of the research population. This study covered only local Muslims in Malaysia. Hence, leading to a relatively small sample size, rendering these results applicability only to the Malaysian Muslims context.

It also may influence the generalizability of the research outcome. Moreover, the results cannot be expected to explain the behaviour of all Muslims regarding homestays visitation in general. Thus, future studies could increase the sample size, and including international Muslim participants would be beneficial. Henceforth, it is great for future studies to gather data from foreign Muslims in other countries to obtain a more comprehensive representation of the population. Likewise, it is also advised that the conceptual model of this study can be further developed in the future by including other mediating or moderating variables such as religiosity and attitude. The second limitation is that only halal awareness over intention were measured in the present study. Other predictors, such as attitude, subjective norms, perceived behavioural control, halal image, and religiosity, could be considered in future research. Also, it is suggested that future research consider the moderating effect of other variables, such as religiosity and culture. Finally, this study used quantitative data, which sometimes miss certain information and restrict the respondents' opinions on the study variables. For future studies, applying a mixed-method approach might produce better results.

\section{References}

Ajzen, I. (1991). The theory of planned behavior. Organizational Behavior and Human Decision Processes, 50(2), 179-211. doi:10.1016/0749-5978(91)90020-T.

Ambali, A. R., \& Bakar, A. N. (2013). Halal food and products in Malaysia: People's awareness and policy implications. Intellectual Discourse, 21(1):7-32.

Ambali, A. R., \& Bakar, A. N. (2014). People's awareness on halal foods and products: Potential issues for policy-makers. Procedia-Social and Behavioural Sciences, 121(2014), 3-25.

Aziz, Y. A., \& Chok, N. V. (2013). The role of halal awareness, halal certification, and marketing components in determining halal purchase intention among non-muslims in Malaysia: A structural equation modelling approach. Journal of International Food and Agribusiness Marketing, 25(1), 1-23.

Awan, H. M., Siddiquei, A. N., \& Haider, Z. (2015). Factors affecting Halal purchase intention evidence from Pakistan's Halal food sector. Management Research Review, Vol 38 (6), 640-660. 
Azam, A. (2016). An empirical study on non-Muslim's packaged Halal food manufacturers: Saudi Arabian consumers' purchase intention. Journal of Islamic Marketing, Vol 7(4), 441-460.

Bellows, A. C., Alcaraz, G., \& Hallman, W. K. (2010). Gender and food, a study of attitudes in the USA towards organic, local, US grown, and GM-free foods. Appetite, 55(3), 540550. doi: 10.1016/j.appet.2010.09.002.

Bonne, Karijn, Verbeke, \& Wim. (2006). Muslim consumer's motivations towards meat consumption in Belgium: Qualitative exploratory insights from means-end chain analysis. Anthropology of Food, 5. 2-24.

Battour, M. M., Ismail, M. N., \& Battor, M. (2010). Toward A Halal Tourism Market. Tourism Analysis, 15(4), 461-470.

Battour, M., Ismail, M. N., \& Battor, M. (2011). The impact of destination attributes on Muslim tourist's choice. International Journal of Tourism Research, 13(6), 527-540.

Battour, M., Battor, M., \& Bhatti, M. A. (2013). Islamic attributes of destination: Construct development and measurement validation, and their impact on tourist satisfaction. International Journal of Tourism Research, 16(6), 556-564.

Blanchard, C. M., Fisher, J., Sparling, P. B., Shanks, T. H., Nehl, E., Rhodes, R. E., Courneya, K. S., \& Baker, F. (2009). Understanding adherence to 5 servings of fruits and vegetables per day: A theory of planned behavior perspective. Journal of Nutrition Education and Behavior, 41(1), 3-10.

Chen, J., Lobo, A., \& Rajendran, N. (2014). Drivers of organic food purchase intentions in mainland China-evaluating potential customers' attitudes, demographics and segmentation. International Journal of Consumer Studies, 38(4), 346-356. doi:10.1111/ijcs.12095.

Chin, W. W. (1998). The partial least squares approach to structural equation modelling. In Marcoulides, G. A. (Ed.), Modern Methods for Business Research. Mahwah, NJ: Lawrence Erlbaum Associates.

Chua, B., Lee, S., Kim, H., \& Han, H. (2019). Investigation of cruise vacationers' behavioral intention formation in the fast-growing cruise industry: The moderating impact of gender and age. Journal of Vacation Marketing, 25, 51 - 70.

Cohen, J. (1988), Statistical Power Analysis for the Behavioural Sciences, Erlbaum, Hillsdale.

Correia, A., Santos, C. M., \& Barros, C. P. (2007). Tourism in Latin America: a choice analysis. Annals of Tourism Research, 34(3), 610-629.

Courneya, K. S. (1994). Predicting repeated behavior from intention: the issue of scale correspondence. Journal of Applied Social Psychology, 24(7), 580-594.

Conner, M., \& Armitage, C. J. (1998). Extending the theory of planned behavior: review and avenues for further research. Journal of Applied Social Psychology, 28(15), 1429-1464.

Deuraseh, N. (2009). Lawful and unlawful foods in Islamic law focus on Islamic medical and ethical aspects. International Food Research Journal, Vol 16, 469-478.

Daily Express. (2020). Sabah's homestays among the highest earners in Malaysia. Retrieved from http://www.dailyexpress.com.my/news/146244/sabah-s-homestays-amonghighest-earners-in-m-sia/.

De Leeuw, A., Valois, P., Morin, A. J., \& Schmidt, P. (2014). Gender differences in psychosocial determinants of university students' intentions to buy fair trade products. Journal of Consumer Policy, 37(4), 485-505. doi:10.1007/s10603-014-9262-4. 
Emanuel, A. S., McCully, S. N., Gallagher, K. M., \& Updegraff, J. A. (2012). Theory of Planned Behavior explains gender difference in fruit and vegetable consumption. Appetite, 59(3), 693-697. Doi: 10.1016/j.appet.2012.08.007.

Fishbein, M., \& Ajzen, I. (1975). Belief, attitude, intention and behaviour: An introduction to theory and research.

Fornell, C., \& Larcker, D. F. (1981). Evaluating Structural Equation Models with Unobservable Variables and Measurement Error. Journal of Marketing Research, 18, 39-50.

Ghadikolaei, F.S. (2016). The effect of halal signs and symptoms on consumers' purchase intention in Muslim and non-Muslim countries - A review. International Journal of Business and Management Invention, Vol 5(7), 44-49.

Grogan, S. C., Bell, R., \& Conner, M. (1997). Eating sweet snacks: Gender differences in attitudes and behaviour. Appetite, 28(1), 19-31. doi:10.1006/appe.1996.0067.

Haus, I., Steinmetz, H., Isidor, R., \& Kabst, R. (2013). Gender effects on entrepreneurial intention: A meta-analytical structural equation model. International Journal of Gender and Entrepreneurship, 5(2), 130-156. https://doi.org/10.1108/17566261311328828.

Hasan, Mashita, Sabtu, N., \& Sahari, N. (2016). Syariah Compliant Homestay in Malaysia: Formulating Legal Framework.

Henderson, J. C. (2003). Managing tourism and Islam in peninsular Malaysia. Tourism management, Vol 24(4), 447-456. doi:10.1016/S0261-5177(02) 00106-1.

Henseler, J., Ringle, C. M., and Sarstedt, M. (2015). A new criterion for assessing discriminant validity in variance-based structural equation modelling. Journal of the Academy of Marketing Science, 43(1), 115-135. doi:10.1007/s11747-014-0403-8.

Hwang, J., Kim, H. (2019). Consequences of a green image of drone food delivery services: The moderating role of gender and age. Business Strategy Environment, 28, 872-884.

Ibrahim, Y. (2004). Homestay Programme in Malaysia. ASEAN Journal on Hospitality and Tourism, 3(1), 65-75.

Jeaheng, Y., Al-Ansi, A., \& Han, H. (2019). Halal-friendly hotels: impact of halal-friendly attributes on guest purchase behaviors in the Thailand hotel industry. Journal of Travel and Tourism Marketing, 36(6), 729-746. https://doi.org/10.1080/10548408.2019.1631940.

Kasim, M. M., Kayat, K., Ramli, R., \& Ramli, R. (2016). Sustainability Criteria for the Malaysia Homestay Programme. International Review of Management and Marketing, 6, 1-7.

Khraim, H. (2010). Measuring religiosity in consumer research from an Islamic perspective. Journal of Economic and Administrative Sciences, Vol 26(1), 52-78.

Lada, S., Tanakinjal, H. G., \& Amin, H. (2009). Predicting intention to choose Halal products using theory of reasoned action. International Journal of Islamic and Middle Eastern Finance and Management, Vol 2(1), 66-76.

Machali, M., Abdullah, H. R., \& Razak, A. L. (2013). The effect of halal foods awareness on purchase decision with religiosity as a moderating variable a study at higher education institutions in Brunei Darussalam. Journal of Science and Education, 1-23.

Meyers-Levy, J., \& Maheswaran, D. (1991). Exploring differences in males' and females' processing strategies. Journal of Consumer Research, 18(1), 63-70.

https://doi.org/10.1086/209241.

Ministry of Tourism, Arts and Culture Malaysia. (2021). Laporan Statistik Program Pengalaman Homestay Malaysia tahun 2021. Retrieved from http://www.motac.gov.my/en/download/category/11-homestay 
Ministry of Tourism, Arts and Culture Malaysia. (2019). Laporan Statistik Program Pengalaman Homestay Malaysia tahun 2019. Retrieved from http://www.motac.gov.my/en/download/category/11-homestay

Nguyen, T. D., Nguyen, T., \& Barrett, N. J. (2010). Consumer ethnocentrism, cultural sensitivity, and intention to purchase local products evidence from Vietnam. Journal of consumer behaviour, Vol7(1), 88-100.

Oh, H., Park, S., DeMicco, F. (2002). Age- and gender- based market segmentation: A structural understanding. International Journal Hospitality Tourism Admin, 3, 1-20.

Oktadiana, H., Pearce, P., \& Chon, K. (2016). Muslim travelers' needs: What don't we know? Tour. Management Perspective, 20, 124-130.

Othman R., Azman A., Hashim K. S. H. Y., Radin H., Adzhar M., Mahamod L. H., Fadzillah, N. A. (2019). Assessment of Agro-Based Homestay Activities towards Muslim Friendly Tourism. International Journal of Academic Research in Business and Social Sciences, 9(2), page 901-909.

Olya, Hossein, \& Al-Ansi, A. (2018). Risk assessment of halal products and services: Implication for tourism industry. Tourism Management, 65, 279-291.

Rapport, L., Peters, G. R., Downey, R., McCann, T., \& Huff-Corzine, L. (1993). Gender and age differences in food cognition. Appetite, 20(1), 33-52.

Rasli, A. (2013). Factors Affecting Entrepreneurial Intention among Graduate Students of Universiti Teknologi Malaysia, 4 (2), pp. 182-188.

Riaz, Mian, \& Chaudry, M. M. (2004). The value of Halal food production. INFORM International News on Fats, Oils and Related Materials. 15. 698-700.

Ryu, K., \& Han, H. (2010). Predicting tourists' intention to try local cuisine using a modified theory of reasoned action: The case of New Orleans. Journal of Travel and Tourism Marketing, 27(5), 491-506. doi:10.1080/10548408.2010.499061.

Said, M., Hassan, F., Musa, R., \& Rahman, N. A. (2014). Assessing Consumers' Perception, Knowledge and Religiosity on Malaysia's Halal Food Products. Procedia-Social and Behavioural Sciences, Vol 130, 120-128.

Sekaran, U., \& Bougie, R. (2016). Research Methods for Business: A Skill Building Approach. John Wiley \& Sons.

Shaari, J. A. N., \& Arifin, M. N. S. (2009). Dimension of Halal purchase intention: A preliminary study. In American Business Research Conference, New York, USA, 1-15.

Suki, N. M., \& Salleh, A. S. A. (2016). Does Halal image strengthen consumer intention to patronize Halal stores? Journal of Islamic Marketing, Vol 7(1), 120-132.

Swan, J. (1981). Disconfirmation of expectations and satisfaction with a retail service. Journal of Retailing, 57(3), 49-66.

Tang, Z., Luo, J., \& Xiao, J. (2011). Antecedents of intention to purchase mass customized products. Journal of Product \& Brand Management, 20(4), 316.

Doi: $10.1108 / 10610421111148333$.

Teng, P. K., \& Jusoh, W. J. (2013). Investigating student awareness and usage intention towards Halal labelled cosmetics and personal care products in Malaysia. In 4th International Conference on Business and Economic Research (4th ICBER 2013), Bandung, Indonesia.

Tiraieyari, N., Ricard, R. M., \& McLean, G. N. (2019). Factors influencing volunteering in urban agriculture: Implications for recruiting volunteers. Urban Forestry and Urban Greening, 45, 126372, pp. 1-9. Doi: 10.1016/j.ufug.2019.126372. 
Ting, H., De Run, Ernest, H., Cheah \& Chuah, F. (2016). Food Neophobia and Ethnic Food Consumption Intention: An Extension of the Theory of Planned Behaviour. British Food Journal. Vol. 118, pp. 2781-2797.

Wu, P. C., Yeh, G. Y. Y., \& Hsiao, C. R. (2011). The effect of store image and service quality on brand image and purchase intention for private label brands. Australasian Marketing Journal (AMJ), Vol. 19 (1), pp. 30-39.

Yunus, N. S. N. M., Rashid, W. E. W., Ariffin, N. M., \& Rashid, N. M. (2015). Muslim's Purchase Intention towards Non-Muslim's Halal Packaged Food Manufacturer. Procedia- Social and Behavioral Sciences, Vol 130, 145-154. Doi 10.1016/j.sbspro.2014.04.018.

Zamani-Farahani, H., \& Henderson, J. C. (2010). Islamic tourism and managing tourism development in Islamic societies: The cases of Iran and Saudi Arabia. The International Journal of Tourism Research, 12(1), 79.

Zakaria, N. B., Yunos, R. M., Mahmood, C. F. C., Anita, R., \& Said, J. (2017). The effect of consumers' interest, information access and spending willingness on halal products trustworthiness. Asia-Pacific Management Accounting Journal, Vol. 12 No. 2, pp. 183200. 